\title{
木質ペレット燃料の着火特性
}

\section{Ignition Characteristics of Woody Pellet Fuel}

山口績（岩大院）正 北野 三千雄（岩手大）正 藤田 尚毅（岩手大） 金子昌晴（岩手大）

Isao Yamaguchi, Iwate University, 4-3-5 Ueda,Morioka,020-8551

Michio Kitano, Naotake Fujita and Masaharu Kaneko, Iwate University Key Words: Woody Pellet, Ignition Characteristics, Density

\section{1. 緒言}

近い将来枯渴する心配がある化石燃料の代替然料の一つとして, バイオマス燃料(エネルギー)が注目されているが,バイオマスの基 本的な燃焼の挙動，熱分解は未だ十分には解明されていない，

本研究では，木質バイオマスを用いたペレット燃料の着火 特性を調べるために，ホワイトペレット（スギ，ヒノキの心 材), バークペレット（スギ樹皮）を様々な時間で乾燥させ, 実際の使用条件に近い加熱面上に置いたときの着火遅れ時間 を測定した。併せてペレットの熱重量分析を行い, 熱分解举 動についての調査も行うことで, 木質ペレット燃料の着火に ついての基礎的知見を得ることを目的とする.

\section{2. 実験方法}

本実験で用いた装置を図 1 に示す。

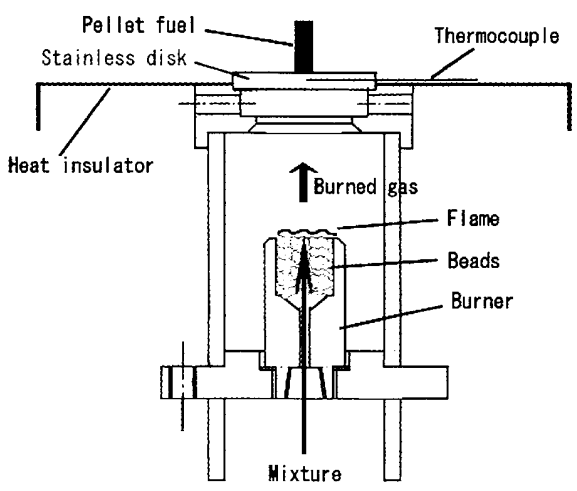

Fig.1 Experimental apparatus.

図 1 に木質ペレットの着火特性を調べるための装置を示す，ガ スバーナでステンレスの円盤（直径 $45 \mathrm{~mm}$ ，厚さ $5 \mathrm{~mm}$ ）を加熱 し，その上にペレットを横置き，維置きと区別して置き，着火ま での様子を調べた。 バー十による火炎と熱が円盤上に回り込まな い上うに, 周りに断熱材のカバーを設けた. ここで, 横置きとは, ペレットの軸方向がステンレス円盤に平行になる様な置き方であ り，繸置きとは，ペレットの軸方向がステンレス円盤に垂直にな る様な置き方である。

加熱したステンレス円盤の中心部の温度を熱電対（シースタイ プ, K型) で測定し，これを加熱面温度とした。温度は供給混合 気の当量比を変えるか，ステンレス円盤を上下させて調節し， $700^{\circ} \mathrm{C}$ から $775^{\circ} \mathrm{C}$ まで $25^{\circ} \mathrm{C}$ 刻みで測定した.

試料としてホワイトペレット（スギ，ヒノキの心材），バー クペレット（スギ樹皮）を使用した。直径は，スギ心材・樹皮 共に $6.5 \mathrm{~mm}$ ，七ノキ心材は $6 \mathrm{~mm}$ であり，長さを $10 \mathrm{~mm}, 15 \mathrm{~mm}$, $20 \mathrm{~mm}$ に調節した. 乾燥を行う場合は, マントルヒーターで $100^{\circ} \mathrm{C}$ に加熱, 保温されている真ちゅう製の乾燥容器内で乾燥を行った。

\section{3. 実験結果及び考察}

\section{1 乾燥がペレット密度に及ぼす影響}

ペレットの重量は, 乾燥時間についてスギ心材と樹皮では 30 分, ヒノキ心材では 45 分まで大きく減少し, その後緩や かに減少していく，よって，それまでの乾燥でほぼ水分が蒸 発していると考えられる。一方, ペレットは乾燥によって体
積変化が起こる。図 2 は, 測定された重量, 体積から算出し たペレットの密度（かさ密度＝重量／体積）の乾燥時閒によ る変化を示す。

注目すべきは密度変化に最小值が見られたことである。こ の理由は, 最小となる乾燥時間までに重量減少がほぼ終了し ているのに対して, ペレットの収縮がその後も続き, 重量が あまり変化しないのに体積が減少しているためである.

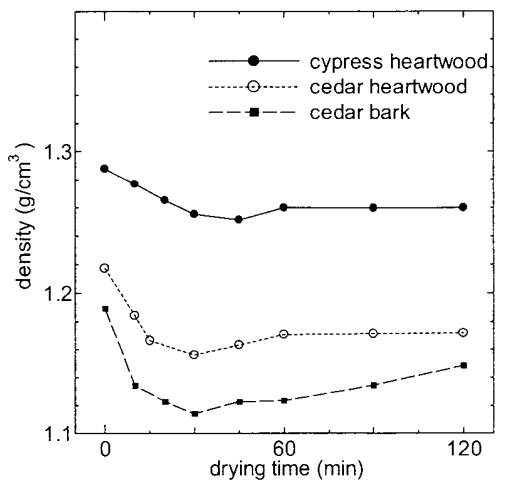

Fig.2 Relationship between drying time and density

\section{2 着火特性}

ペレットの燃焼は，発煙反応，赤熱反応，着火，有炎燃焼， 消炎，そして燃え尽きるというように進行していく，赤熱然 焼部分から供給される可燃性ガスと雰囲気中にある酸素が燃 焼反応を起こし有炎燃焼を生じる。この火炎から発生した熱 の一部が赤熱燃焼部分へ供給され，未燃部分が予熱され熱分 解や蒸発を起こす。これによって生じた可燃性ガスが火炎に 供給され有炎燃焼の継続を助ける。このように有炎燃焼と赤 熱然焼の間には，非常に密接な関係がある.

乾燥時間やペレットの長さを変えて行った着火実験におい て，着火する場合とそうでない場合が確認できた，以下の図 に示すのは, 測定した全ての乾燥時間、ペレット長さに対し て着火した時の最低試験温度における結果であるが，スギ， ヒノキ心材, スギ樹皮について, それぞれの横置きでは $750^{\circ} \mathrm{C}$, $700^{\circ} \mathrm{C}, 775^{\circ} \mathrm{C}$, 縦置きでは $725^{\circ} \mathrm{C}, 725^{\circ} \mathrm{C}, 750^{\circ} \mathrm{C}$ であった。

\subsection{1 スギ心材及びヒノキ心材}

図 3，4 にスギ心材及びヒノキ心材における横置き，縦置き での着火実験の結果を示寸，基本的に，乾燥時間が長くなれ ば着火時間も短くなる傾向にあった。元々木質ペレットは製 造過程に执いて含水率を低く $(8 \sim 13 \%)$ 抑えてあり，他の木材 チップなどに比べ着火し易くなっている。しかし，貯蔵して いる閒に余分な水分を含んでしまう事は避けられない。乾燥 することでこの余分な水分を蒸発させたため，着火時間が低 くなったものと考えられる.

横置きに注目すると，スギ，ヒノキ共にペレットの長さに よって着火時間に差は見られなかった。横置きの場合, ペレ ットが長くなっても単位体積当たりに流入する熱量は変わら ず，各長さにおいて同様の熱供給状態にあったと考えられる。 そのため, ペレットの長さによらず着火時閒はあまり変わら なかったものと思われる.

これに対し，縦置きの場合 $10 \mathrm{~mm}, 15 \mathrm{~mm}, 20 \mathrm{~mm}$ と長く 
なるにつれて，着火時間が長くなる傾向が見られた。ペレッ 卜を縦置きにすると, 加熱される面積は長さによらず一定に なる。よってペレットが長くなると，単位体積あたりに流入 する熱量が減少するために，熱容量が大きな順に着火時間が 長くなったものと思われる.

また乾燥時間に注目すると， 3 ，1において密度が最小值 をとった乾燥時間付近で，着火時間が最小となる傾向が見ら れた。密度が小さければ，ペレット表面および内部の空隙部 が多いといえる。そのため，実質の表面積も増加し，酸素の 供給量も増え, 反忘の進行も促進され易くなったため, 密度 が最小となる乾燥時間において, 着火時間も早くなったと考 えられる.しかしながら, 図 2 の樹種間の密度を比較すると, スギ樹皮は密度が低いが，後述する様に着火性は最も低いこ とから密度が低いからといって着火し易いとは必ずしも言え ない。これについては熱重量分析の結果から言及寸る.
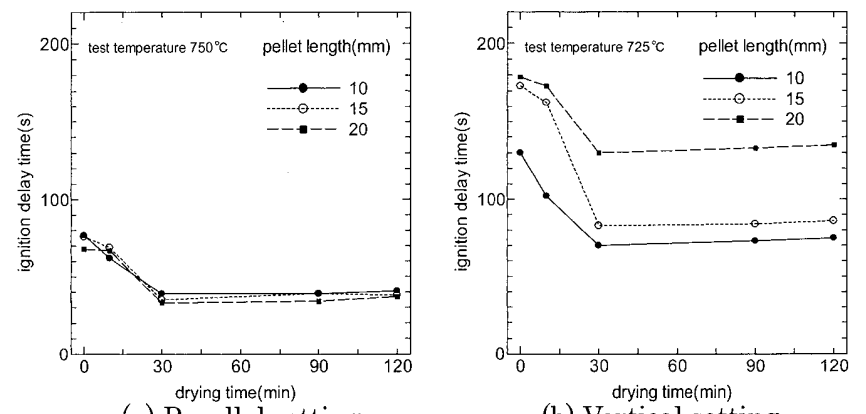

(a) Parallel setting

Fig.3 Results of ignition experiment on cedar heartwood

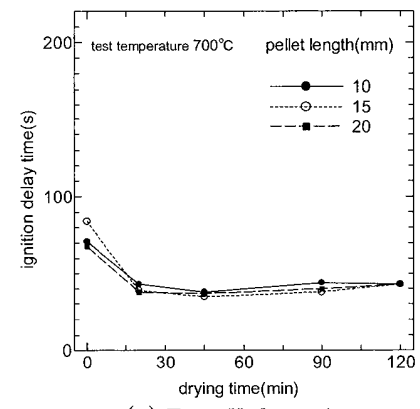

(a) Parallel setting

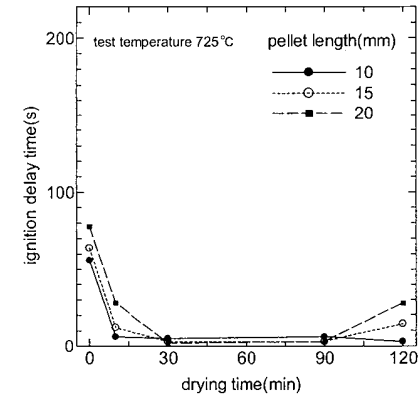

(b) Vertical setting

Fig.4 Results of ignition experiment on cypress heartwood

\section{2. 2 スギ樹皮}

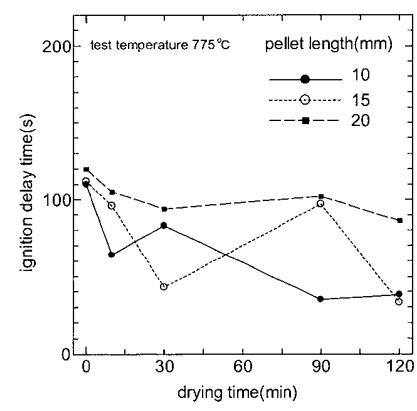

(a) Parallel setting

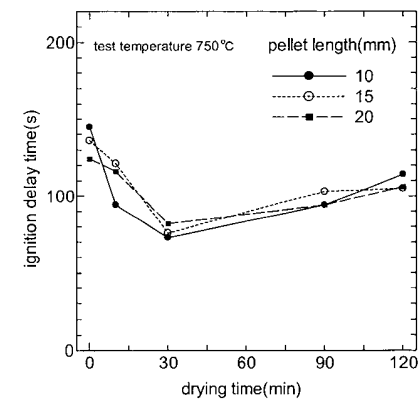

(b) Vertical setting

Fig.5 Results of ignition experiment on cedar bark

図 5 にスギ樹皮における縦置き, 横置きでの着火実験の結 果を示す．スギ樹皮については，スギ，ヒノキ心材で見られ た乾燥時間やペレットの長さに関する傾向は出なかった，樹 皮は, 心材に比心主成分以外の副成分が比較的多く, 燃焼し た後の灰分が多いのが大きな特徵である。 また，ペレットを 形成している木材の粒度も大きいものであった。これらの理 由から，樹皮は心材のような比較的安定した燃焼が得られな かったと考えられる。

\section{3 熱重量分析}

図 6 にスギ，ヒノキ心材，スギ樹皮の熱重量分析の結果を 示す，重量減少速度 DTGに着目すると，そのピークはヒノキ 心材，スギ心材，スギ樹皮の順で速いことが分かった． 3. 2 で述べているように，全ての条件で着火する温度から判断 すると，ヒノキ心材，スギ心材，スギ樹皮の順に着火し易い ことが分かる。重量減少は可燃ガスの放出に直接繋がる。よ って，可然ガス放出速度，即ち単位時間での放出量が多いと 着火し易い状況を作り出すと思われる.

また，横置きと縦置きを比較した時，スギ心材，樹皮につ いては縦置きでの最低着火温度が低くなり，ヒノキ心材では 高くなることが分かった。着火に至るためには，可燃ガス供 給と熱エネルギ一供給の両方が十分に行われる必要がある.

実験において，縦置きは横置きよりも，有炎燃焼を生じなか った時の燃え尽きるまでの時間が長い結果となった，従って 縦置きの方が流入熱量は低いと考えられる，そのために，可 燃ガス放出量が大きいヒノキ心材では，赤熱燃焼部から着火 に必要な熱エネルギーが供給される前に，ペレット内部に残 留する揮発分が少なくなってしまい，十分な可燃ガスの供給 が出来ない状況になったと考えられる.

揮発分の残留量や赤熱燃焼の進行は，ペレットの初期状態 や赤熱燃焼開始までの時間に左右される。つまり乾燥時間や 密度, 水分など多くの要因に影響されると考えられる。

これらのことにより着火の特性は，赤熱燃焼開始までの時 間とその時間における揮発分の残留量が大きく関わっている と考えられる.

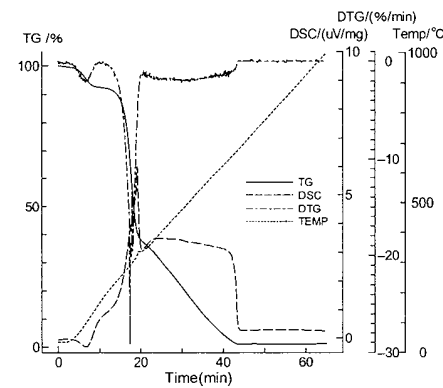

(a) Sedar heartwood

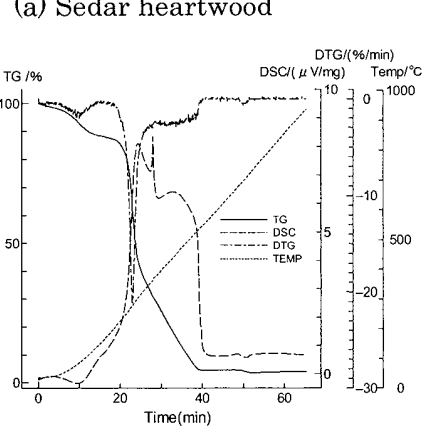

(c) Cedar bark
Fig.6 Results of Thermogravimetric Analysis

\section{4. 結言}

木質ペレット燃料の燃焼実験において，以下のような結論 を得た。

1. 単純に長時閒乾燥させれば着火時間が短くなるとは限 らない。

2. 一般的に可燃ガス放出量が多ければ着火し易い.

\section{参考文献}

1. 鈴木正太郎, 日本機械学会誌 第 46 巻 138 号 $(2004), 217-223$

2. 武又貴文,木質ペレット燃料の燃焼,岩手大学大学院, 修士論文(H16 年度) 